4. Сторожинська 3. Моральні цінності у житті сучасної людини Психологічні виміри культури, економіки, управління: Науковий журнал. 2016. Випуск IX. С. 146-157.

5. Великий тлумачний словник сучасної української мови / Уклад. і голов. ред. В.Т. Бусел. Київ; Ірпінь : ВТФ «Перун», 2003. 1440 с.

6. Могілевський Л.В. Сутність поняття «норма права». Прикарпатський юридичний вісник. 2016. Випуск 1. С. 14-18.

7. Миронець О.М., Демченко Ю.О., Атаманчук Т. Р. Теоретико-правові аспекти легалізації легких наркотиків. Електронне наукове фахове видання «Юридичний науковий електронний журнал». Запоріжжя, 2017. С. 38-40.

8. Крайник Г.С., Ревякін Д.В., Чорнобривець Р.Є. Окремі питання легалізації проституції та декриміналізації діяльності, пов'язаної з нею. Молодий вчений. 2018. № 4. С. 708-712.

9. Миронець О.М., Капустяк I.О. Теоретико-правові аспекти легалізації проституції. Порівняльно-аналітичне право. 2017. № 4. С. 28-30.

10. Конституція України: Верховна Рада України. Закон України від 28.06.1996 № 254к/ 96-BP. URL: http://zakon2.rada.gov.uaЛaws/show/254к/96-вр.

11. Гладкий В.В. Об'єктивні прояви пенітенціарної корупції. Науковий вісник публічного та приватного права. 2017. Випуск 6. Том 2. С. 187-192.

12. Фуллер Лон Л. Мораль права: пер. з англ. Н. Комарова. Наукове видання. Київ : Сфера, 1999. $232 \mathrm{c}$.

УДК 340.111.5:316.347

DOI https://doi.org/10.32844/2618-1258.2019.5-1.4

ГОЛОВАШ О.О.

\title{
НАЦІОНАЛЬНА МЕНШИНА: СУТНІСНІ ОЗНАКИ ТА ЗМІСТОВНІ ХАРАКТЕРИСТИКИ
}

У сучасному світі не існує держав, які б не мали на своїй території груп, які за своїми етнічними, расовими, мовними чи релігійними відмінностями відокремлені від більшості. Насправді у світі є біля 3000 етнічних або племінних груп, які усвідомлюють власні ідентичність та права. Отже, це проблема не тільки українського народу, але й усього світу. Навіть у сучасну епоху трапляються повідомлення про випадки геноциду окремих меншин. Відповідно до статистичних даних $\mathrm{OOH}$, майже 10-20\% населення світу належить до груп меншин та громад і лише $9 \%$ держав світу є технічно однорідними, з понад 190 суверенних держав, понад 175 є багатоетнічними за своїм складом.

У міжнародному праві комплексне визначення поняття «меншина» потребує уточнення та доповнення, незважаючи на те, що це питання неодноразово виносилося на форуми ООН починаючи з 1950 року. Багато держав таких, як Австрія, Чилі, Чехія, Словаччина, республіки колишнього СРСР, Гаїті, Угорщина, Індія, Румунія, Філіппіни, виступили проти єдиного визначення поняття «меншина». Отже, певною мірою небажання окремих держав, узагальнююче визначення такого надзвичайного важливого поняття, як «меншина», є однією з перешкод єдиного розуміння складного політико-правового явища.

Людство доволі жорстоко поводиться з меншинами, що призводить до несправедливої соціально-економічної сегрегації в окремих випадках. Однією з найважливіших причин минулих та сучасних етнічних криз у світі є той факт, що етнічні меншини виключені з участі у процесах розподілу влади та прийняття рішень в їх політичних системах. Формальні чи неофіційні домовленості щодо розподілу

( С ГОЛОВАШ О.О. - аспірант кафедри теорії та філософії права (Національний юридичний університет імені Ярослава Мудрого) 
влади не гарантуються всім меншинам, окрім того, правовий захист та толерантність до них у багатоетнічних державах фактично неможливі. Насильство, яке вчиняється над членами меншин, є свідченням нерівного ставлення та приниження прав людини. Незважаючи на численні конвенції, постанови ООН, дискримінація за різними ознаками продовжує існувати. Тому правові механізми права меншин потребують всебічного дослідження з метою подальшого вдосконалення захисту прав людини в усьому світі.

Ключові слова: меншина, національна меншина, етнічна мениини, толерантність, етнополітика, дискримінація, ідентичність, толерантність, багатоетнічHicmb.

Protecting minorities is not a new topic today. The root cause of this problem is discrimination, exclusion, denial, and suppression. There are almost no States that do not have minorities on their territory and are separated from the majority by their ethnic, racial, linguistic or religious differences. In fact, there are about 3,000 ethnic or tribal groups in the world that are aware of their identity and rights. So, this is a problem not only for the Ukrainian people, but also for the whole world. Even in this modern era, there are reports of cases of genocide of minorities. According to statistics, UN estimates show that almost $10-20$ percent of the world's population belongs to minority groups and communities, and only 9 percent of the world's States are technically homogeneous today. With more than 191 politically sovereign States existing, more than 175 are multi-ethnic in composition.

There is no definitive definition of the concept of "minority" in the world, and one of the reasons is that the majority of States in General oppose the development of any definition, this issue has been submitted to UN forums since 1950. Many States, such as Austria, Chile, the former Czechoslovakia, the former Yugoslavia, the former USSR, Haiti, Hungary, India, Romania and the Philippines, opposed the definition of a minority. Thus, it can be said that the reluctance of the majority of States to reach a final and constructive definition has become the main obstacle to the development of minority rights. Perhaps an appropriate definition could be found if the international community really wanted it. For the past 60 years, since the creation of the UN, States have been dragging their feet on this important issue.

Humanity treats minorities fairly harshly, which leads to injustice and unfair socio-economic segregation in the maximum cases. One of the most important reasons for past and long-term ethnic crises in the world is the fact that ethnic minority groups are excluded from participating in the processes of power distribution and decision-making in the political system. Formal or informal arrangements for the distribution of power are not guaranteed to all minorities, and legal protection and tolerance for them are not guaranteed either, so peace is not possible in these multi-ethnic States. The violence that rises against members of minorities is a symptom of unequal treatment and the humiliation of human rights. Despite numerous conventions and UN resolutions, this discrimination still exists. Therefore, the rights of minorities must be protected and promoted throughout the world.

Key words: national and ethnic minorities, tolerance, ethno-politics, discrimination, identity, tolerance, multi-ethnicity.

Вступ. Питання захисту прав релігійних, етнічних, національних меншин належить до найбільш поширених проблем, як міжнародного, так і національного законодавства. Можна стверджувати, що ця проблема виникла ще в XVI-XVII ст., коли з'явилися перші акти про захист прав меншин. Потреби регулювання відносин між різними групами всередині держави, а також та обставина, що проблеми меншин мали здебільшого міждержавний характер (меншість в одній державі часто виявлялася більшістю в сусідній), породили особливі норми, які мали переважно захисний характер.

Незважаючи на те, що більшість держав характеризуються складною конфесійною, лінгвістичною та етнічною структурами, тобто є поліетнічними, поліконфесійними та багатомовними, багато урядів таких держав заперечують існування проблем у правовому забезпеченні рівноправності меншин у межах своїх національно-правових систем. 
Постановка завдання. Метою статті є доволі актуальне питання термінологічного характеру щодо визначення змісту та сутності поняття національної меншини, яке потребує комплексного дослідження. Сучасна юридична наука використовує різні поняття національної меншини для позначення цього явища, що ускладнює розуміння та вирішення достатньо складної проблеми - забезпечення рівних прав і можливостей національних меншин.

Інститут захисту прав національних меншин сформувався досить давно, у зв'язку з чим у роботах таких вчених, як А.Х. Абашидзе, В.П. Блищенко, Т.К. Євменова, Ю.А. Дубровіна, В.Ф. Погорілка, М.П. Рабіновича, Ю.І. Римаренка, В.М. Селіванова, С.А. Тихонової, Ю.М. Тодики та інших, досліджується правовий статус національних меншин, включаючи колективні та «особливі» права, право на самовизначення, а також окремі аспекти цієї проблематики.

Результати дослідження. У літературі неодноразово наголошувалося, що наділення національних меншин тим самим обсягом прав, що й осіб, які становлять більшість, не веде автоматично до фактичної рівності їх правового становища, хоча і $є$ необхідною передумовою. У сучасному світі використовуються різноманітні засоби гарантування та захисту прав національних меншин: це і міжнародно-правове регулювання, що має глобальний чи регіональний характер, регулювання в масштабах держави i, зрештою, регулювання в межах окремих регіонів, або локальне регулювання.

Як відомо, меншість складається з таких груп: «етнічна/національна меншина», «релігійна меншина», «расова меншість», «гендерна меншість», «вікова меншість», «сексуальна меншість», «економічна меншість» тощо. Якщо розглядати етнічні меншини, важно знайти єдиного визначення цього явища в міжнародному праві. Оскільки жоден із термінів не визначено, дослідникам та політикам надається «карт-бланш» щодо їх вибору. Міжнародні документи містять велику кількість різноманітних позначень цієї категорії: «меншини», «етнічні меншини», «національні меншини», «расові та етнічні групи», «релігійні та мовні меншини» тощо. Загальновідомі словники включають таке визначення: «Меншість - це група людей тієї ж раси, культури чи релігії, яка проживає у тому місці, де більшість людей навколо них інша раса, культура чи релігія» [1, с. 104-106]. Ще одне джерело визначає етнічну приналежність як групу людей, які мають спільні фізичні, психічні особливості та культурно-генетичну спадщину, що відрізняє їх від основної групи [2, с. 9-12].

В юридичній літературі спостерігається багатоманітність підходів щодо тлумачення поняття «національна меншина» та іiі співвідношення 3 поняттям «етнічна меншина». Так, T.M. Рудницька [3] та А.М. Василенко [4] ототожнюють поняття етнічні і національні меншини та стверджують, що етнічні меншини - це національні меншини в етнічному складі нації, що $\epsilon$ доволі спірним висновком, оскільки поняття «національна меншина» та «етнічна меншина» не тотожні, хоча й близькі за змістом, оскільки є похідними від категорій «нація» і «етнос». Поняття «етнічна меншина» ширше за змістом, ніж «національна меншина». Тому в більшості досліджень «національну меншину» визначають як сукупність осіб певної національної приналежності, частина яких мешкає в іншій державі або навіть $є$ титульною нацією в іншій державі. На відміну від національної меншини, етнічну меншину становлять усі особи певної національно-етнічної приналежності, які проживають на законних підставах у межах конкретної держави, є іії громадянами та не мають власної держави за ії межами (не є нацією, яка дала назву державі) або взагалі не визнаються нацією, а лише вважаються етнічним утворенням.

Інші вчені дотримуються тієї думки, що національні меншини є етнічними групами. Так, B.O. Нікітюк вживає термін «етнонаціональні меншини» як етнічні групи, відмінні від інших груп, зокрема національної більшості, що проживає на території суверенної держави [5, с. 8]. В.Б. Свтух, аналізуючи поняття етнічних і національних меншин, вважає їх близькими за змістом, але не синонімами. Він грунтуються на тому, що національна меншина є різновидом етнічної меншини [6, с. 6-9]. В. Кимлічка застосовує поняття «етнокультурна меншина» як узагальнений термін для позначення всіх груп населення, які за своїми етнічними ознаками відрізняються від домінантної групи (більшості, титульного етносу) [7, с. 32]. Варто частково погодитись із тим, що етнонаціональні чи етнокультурні меншини - це певна група людей, яка становить меншу частину населення країни та не займає панівного становища, з огляду на їх національність, критеріями самовизначення якої є наявність власної мови, культурних і релігійних традицій. Вплив таких факторів, як етнічна та культурна диференціація, існування різних мовних груп і держави, в якій національна група є більшістю, становить самоідентифікацію національної меншини. Однак поняття «етнонаціональні меншини» $є$ некоректним, оскільки поняття «етнос» та «нація» не тотожні та не можуть об'єднуватися однією категорією, тому що мають різне значення. Таким чином, з'ясування змісту та сутності поняття «національна меншина»є важливим чинником 
розуміння правового статусу національних меншин, комплексу їхніх прав і можливостей брати участь у державотворчих процесах як на регіональному, так і на загальнодержавному рівні.

Термін «національна меншина» вживається в актах багатьох міжнародних організацій, в яких під «національною меншиною» розуміють громадян певної держави. Поняття «національна меншина» використовується в першому розділі Рамкової конвенції про захист прав національних меншин, а саме у ст. 5 цього документа, і позначає групи осіб, які проживають на території певної держави і є ії громадянами, підтримують тривалі, міцні зв'язки з країною, демонструють характерні етнічні, мистецькі, релігійні або лінгвістичні характеристики, мотивують зацікавленість зберегти те, що становить їх спільну індивідуальність, культуру, традиції, релігію або мову [8]. Так, правові акти, прийняті як самою Радою Європи, так і Організацію з безпеки і співробітництва в Європі спрямовані на забезпечення національним меншинам широких додаткових прав.

Практично в кожному суспільстві є етнічні меншини, статус яких здебільшого зумовлений кількісними показниками їх чисельності, але іноді $є$ й етнічні групи, що становлять кількісну більшість, залежну від меншості. Статус меншини також зумовлений багаторічною присутністю меншин на території, де вона проживала. Щоб уникнути конфліктів та поширювати толерантність, суспільство має бути ознайомлене з ідеєю культурного плюралізму. Цього можна досягти завдяки підтримці різних державних органів, які допоможуть поширювати повагу до багатоманітності культур, присутніх у кожному суспільстві.

Представники національних меншин нерідко стикаються з такими явищами, як акультурація, двомовність, відчуження, культурний детермінізм, етноцентризм, етнофобія, культурний шок тощо. Зазначені тенденції можливі через те, що групи меншин сприймаються як «інші» в суспільстві, а також через відсутність необхідного ступеня толерантності в суспільстві, всі вищезазначені явища характерні для сприйняття «іншого» 3 точки зору міжкультурного спілкування. Акультурація - це процес, при якому члени однієї культурної групи запозичують переконання, поведінку, ставлення, цінності або мовні уподобання іншої групи. Хоча акультурація зазвичай йде в іншому напрямі, а група меншин лише переймає звички та мовні зразки домінуючої групи. Це так само може бути взаємно, тобто домінуюча група приймає типові для меншості звички. Але коли культурні практики меншин відхиляються від загальноприйнятих, ключових поведінкових закономірностей, що застосовуються в тому чи іншому суспільстві, виникають зіткнення, нерозуміння і навіть ворожа поведінка щодо верств населення, які порушують ці правила.

Ці сегменти представлені національними меншинами, які або вирішують дотримуватися цієї культури або ігнорують іiі, просуваючи власний набір культурних зразків. У першому випадку прихильність до культури полегшує життя, допомагає спростити перехід від культурного походження до досвіду нового життя, тим самим робить взаємодію з новою культурою менш болісною і приємнішою. У той час як в іншому випадку, в певний момент меншинам доводиться стикатися з викликами, проблемами або внутрішніми конфліктами - власною війною із самим собою і зовнішнім конфліктом, взаємодіючи із зовнішніми силами, зокрема, більшістю. Отже, між неминучим вибором найбільш доцільнішою $є$ акультурація, яка насправді є двостороннім процесом, і як стверджує антрополог Ф. Боас, «усі люди окультурюються і не тільки меншини» [9, с. 115]. Немає народів, чиї традиції, звичаї, моральні принципи та культура в її широкому розумінні не перебували під впливом іноземних культур.

Ідеї міжкультурного спілкування є ідеями запозиченими, обробленими та адаптованими до власних потреб та оточення, що розвиваються власним чином. У результаті народжується щось нове. Але цілком ізольовані народи не можуть розвиватися повноцінно.

Більшість національних меншини сприйнятливі до етноцентризму, який фактично $є$ власною культурою, що перевершує будь-яку іншу. Етноцентризм характерний для всіх культур і найбільше проявляється в народів колишнього СРСР [10, с. 61]. Ця тенденція оцінювати та інтерпретувати інші культури з власної точки зору яскраво проявляється в контексті відносин більшості та меншин та призводить до конфліктів, якщо представники національних меншин починають переглядати домінуючу культуру крізь вузьку лінзу власної культури й оцінюють всі явища крізь власні стандарти. Члени меншин, які звикли схилятись до порівняльних суджень між власною культурою і домінуючою, припускають, що власна краща, природна, стандартна або більш адекватна. Наслідки етноцентризму можуть бути руйнівними для національних меншин, якщо вони не припинять надавати пріоритет власним культурним традиціям або цінностям, етноцентризм може викликати відчуження спільних елементів від домінуючої культури [10, с. 87]. Якщо меншість відвертається від основної частини населення або відкидає зміни в межах своєї власної 
групи, оскільки не бажає сприймати правила, які встановлені домінуючою культурою, або будує захисні стіни, то, швидше за все, це матиме негативні наслідки, а в результаті зменшить шанси повністю інтегруватися в панівне суспільство. Надмірний етноцентризм може спричинити серйозні проблеми спілкування через вузькість, нетерпимість, неприйняття, а імідж меншини може бути під загрозою і сприйматися у менш сприятливому світлі [11].

Ще одне поширене явище в межах національних меншин - етнофобія (синонім ксенофобії), тобто страх перед етнічною приналежністю, страх перед іноземним. Етнофобія означає забобони щодо конкретного етносу, упереджене ставлення до будь-якої домінуючої групи, яка відрізняється за етнічною приналежністю, релігією чи будь-якими іншими ознаками, демонструє нетерпимість до оточуючих, що споконвіку провокує війни між народами.

Національні меншини визнаються в Україні рівноправними суб'єктами усіх правовідносин, їхній правовий статус має законодавче закріплення у ст. 11 Конституції України. Держава сприяє розвитку етнічної, культурної, мовної та релігійної самобутності всіх корінних народів і національних меншин України. Закон України «Про національні меншини в Україні» визначає національні меншини як групи громадян України, які не є українцями за національністю, виявляють почуття національного самоусвідомлення та спільності між собою.

Механізм захисту прав національних меншин - це система принципів, норм, інституцій та заходів, спрямованих на забезпечення належної реалізації, запобігання порушенню і відновлення порушених прав національних меншин. Захист прав національних меншин в Україні за внутрішньодержавним правом - це сукупність інституційних та нормативних гарантій, інституцій, норм та принципів внутрішньодержавного права України, спрямованих на забезпечення належної реалізації, запобігання порушенню і відновленню порушених прав національних меншин в Україні.

Механізм захисту прав меншин за внутрішньодержавним правом в Україні характеризується неоднозначно, в деяких актах чинного законодавства містяться норми, для практичної реалізації яких замало правових гарантій. Зокрема, згідно зі ст. 2 Декларації прав національностей України, держава забезпечує існування національно-адміністративних одиниць. Однак для функціонування національно-адміністративних одиниць в Україні немає належної законодавчої бази, та й фактично такі національно-адміністративні одиниці в Україні відсутні. Реальна можливість їх створення є маловірогідною. Навіть, якщо є деякі адміністративно-територіальні одиниці, в яких проживають представники виключно однієї національної меншини, варто врахувати, що населення є динамічною, а не статичною категорією, його склад постійно змінюється. Тому створити таку одиницю, яка б задовольняла інтереси певної національної меншини і не обмежувала права інших національних спільнот, на практиці видається малоймовірним. Тому важливо вживати заходи щодо збереження малочисельних національних спільнот України, які не мають своєї «материнської» держави і знаходяться під загрозою зникнення, насамперед це стосується кримчаків та караїмів, які є складниками народу України.

Висновки. Нині залишаються проблеми, пов'язані з меншинами, які необхідно вирішити, і ці питання не $\epsilon$ новими. Попри все, представники національних меншин мали бути повністю інтегровані в суспільство, брати участь та активно користуватися всіма сферами життя. Проте більшість із них стикається з дискримінацією, виключенням, ізоляцією. Багато хто стикається з низкою маргіналізуючих факторів. Необхідно докласти зусиль для просування, захисту та забезпечення рівноправного використання всіх прав та свобод людини, сприяти повазі гідності членів меншин.

Світ сповнений конфронтації між людьми, групами та націями, які думають, відчувають і діють по-різному. Водночас ці люди, групи та нації піддаються загальним проблемам, які вимагають співпраці для їх вирішення. Етнічна приналежність та етнічна ідентичність є найважливішими питаннями в глобалізованому світі, вони вимагають адекватного розуміння та потребують кардинального переосмислення застарілої концепції.

\section{Список використаних джерел:}

1. Пліско В. Щодо правової визначеності поняття «національна меншина». Право України. 2005. № 7. С. 104-106.

2. Антонович М. Права національних меншин в Україні: національне законодавство та міжнародно-правові стандарти. Право Украӥни. 2004. № 6. С. 9-12.

3. Рудницька Т.М. Етнічні спільноти України: тенденції соціальних змін. 2-ге вид., Київ : Інститут соціології НАН України, 1998. С. 176.

4. Василенко А.М. Історико-правове розуміння діаспор і національних меншин. Науковий вісник Чернівецького університету. Чернівці. 2007. Вип. 402. С. 18-23. 
5. Нікітюк В.О. Статус етнонаціональних меншин (порівняльно-правовий аспект): монографія. Київ : Естет, 1996. 186 с.

6. Володимир Є. Державна етнополітика України: нинішні засади і погляд у майбутнє. Українські варіанти. 1997. № 2. С. 4-9.

7. Кимлічка В. Лібералізм і права меншин. Харків : Центр освіт. ініціатив, 2001. С. 176.

8. Рамкова конвенція про захист національних меншин від 1 лютого 1995 р. Права людини в Україні. Київ, 1998. Вип. 21. С. 150.

9. Вавринчук М.П. Етнополітична безпека в системі національної безпеки України на етапі сучасного державотворення : монографія. Київ : Прав. єдність, 2009. 288 с.

10. Вівчарик М. Етнонаціональна політика на етапі українського державотворення. Розбудова держави. 2004. № 12. С. 58-96.

11. Віктовський В., Рабінович П. Право людини на національне самовизначення і проблема бінаціональності. Укр. часопис прав людини. 1995. № 2. С. 99-103. 